\title{
Tax Planning and Firm Value: A Review of Literature
}

\author{
Ofuan .J. Ilaboya ${ }^{1}$, Monday .O. Izevbekhai ${ }^{2} \&$ Friday .I. Ohiokha ${ }^{2}$ \\ ${ }^{1}$ Associate Professor of Accounting, Department of Accounting, Faculty of Management Sciences, University of \\ Benin, Benin City, Edo State, Nigeria \\ ${ }^{2}$ Department of Accountancy, Federal Polytechnic, Auchi, Edo State Nigeria \\ Correspondence: Ofuan .J. Ilaboya, Associate Professor of Accounting, Department of Accounting, Faculty of \\ Management Sciences, University of Benin, Benin City, Edo State, Nigeria
}

Received: May 9, 2016

Accepted: June 17, 2016

Online Published: June 22, 2016

doi:10.5430/bmr.v5n2p81

URL: http://dx.doi.org/10.5430/bmr.v5n2p81

\begin{abstract}
This paper articulates extant literature that is related to tax planning and firm value with a view to identifying gaps for further extensive empirical consideration. Companies are always looking for means to reduce their corporate tax liability, and this has led to some high-level corporate fraud involving tax evasion in both developed and developing countries. This paper, therefore, presents a review of extant literature on tax planning and firm value.

The methodology adopted is a desktop study that is based on deductions from the literature reviewed. The paper identified gaps that require hardcore empirical investigation to reduce the inconsistencies observed in the results of the literature reviewed.
\end{abstract}

Keywords: Tax planning, Effective tax rate, Firm size, Leverage, Capital intensity

\section{Introduction}

The fundamental objective of this paper is to make a modest contribution to the extant literature on the relationship between tax planning and firm value. Company income tax is a fundamental instrument for effective fiscal policy in Nigerian tax system. Taxes are important sources of government revenue even though a tradeoff also exists between company income tax and foreign direct investment. Therefore, issues of the relationship between tax planning and firm value are vital for both firms' strategic decisions and government macroeconomic policies. The corporate objective of any organization is to maximize shareholder's value. Therefore, actions geared towards reducing corporate tax burden which will eventually increase profit is in tandem with the corporate objective.

Irrespective of the importance attached to issues of taxation and tax planning, it has rested in the domain of theoretical expositions in most developing countries. Studies on tax planning and firm value in the Nigerian context are next to non-existent. This forms the basis for the current review of the empirical literature to lay a solid foundation for a robust empirical consideration. It was observed from the literature reviewed that a significant negative relationship exists between tax planning and firm value because of the influence of agency cost theory on tax planning, where information asymmetry generally associated with tax planning could result in moral hazard or other tax planning related risks such as the risk of inspection or investigation by tax authorities. It was also seen in the reviewed literature that tax planning could be considered as steps taken by taxpayers to reduce their tax liabilities so that they can enjoy the benefits of tax savings.

Tax planning seems not to be valued by shareholders, hence the negative relationship with firm value. The consistent negative correlation observed between tax planning, and firm value was occasioned by the agency cost theory of tax planning where information asymmetry associated with tax planning can result in an ethical dilemma.

The remainder of the paper proceeds as follows: Section two focuses on an empirical review of the literature and section three concludes the study and made recommendations for further research.

\section{Literature Review}

\subsection{Firm Value}

Firm value represents the assets owned by a company. It is crucial because it describes the prosperity of the business owners. The manager being the representative of the owners of the business is responsible for optimal maximization of the value of the firm which forms the fundamental objective of any organization. A high firm value indicates that 
the company is prosperous and hence the shareholders' wealth is maximized. The prosperity level of the shareholders and investors are reflected in the firm value. Firm value is an indicator used to assess the performance of a company. Investors also perceive the company through its firm value, and this is related to the stock price. According to Ftouhi, Ayed and Zemzem (2010), the high stock price will make a higher firm value.

Bhabra (2007) opines that firm value is the price paid by the wealthy buyer when a company is sold, and he also sees firm value as the objective value from the public and the orientation of company's survival.

From the preceding, it is clear that firm value is the investors' perception towards a company's success level, and this is usually associated with stock price. Firm value is typically indicated by price to book value (PBV). When the PBV is high, it, therefore, means that the principle of going concern is operational which translates into shareholders' wealth. Modigliani and Miller (1961) opined that firm value is determined by company's asset earnings power. It implies therefore that, when the impact of asset earnings power is positive, the company is doing well, and its asset turnover will be more efficient, and this results in high profit.

Firm value may be measured from two perspectives: from the point of view of accounting measure of profitability: return on assets (ROA), return on equity (ROE), Tobin's Q, net profit margin; and from the stock market perspective, using the share prices from the Stock Exchange market.

\subsection{Tobin's $Q$ as a Measure of Firm Value}

Most empirical studies in tax planning, measure firm value using Tobin's Q. Desai and Dharmapala (2009) used Tobin's q as a proxy for firm value. Tobin's q is the ratio of the market value of a firm to the replacement cost or book value of assets at year end (Allayannis \& Weston, 2001). Tobin's q measures a firm value by scaling the market value of a company's assets with the costs that would be incurred to replace the asset at the current marketplace (Lewellen \& Badrinath, 1997). Tobin's q is utilized as the market value of a firm in most studies (Allayannis \& Weston, 2001; Bhabra, 2007; Desai \& Dharmapala, 2009; McConnel \& Servaes, 1990; and Morck, Shleifer \& Vishny, 1988). The popularity of the index is based on its ability to reflect the performance of management. According to Bhagat and Black (2002), high Tobin's q means that the managers of a firm have produced greater market value from the same asset. This is consistent with the position of Lewellen and Badrinath (1997) that, companies which exhibit Tobin's q greater than "one" means effective use of scarce resources, while Tobin's q less than "One," means the inefficient or poor use of scarce resources. Tobin's q is also widely used as a measure of firm value because of its usefulness in studies of tax avoidance (Desai \& Dharmapala, 2009). The problem with the use of Tobin's q as a measure of firm value is the inability to obtain the exact replacement cost of the assets of a company. Aivazian (2005) therefore suggested a simplified form of calculation that provides an approximation to q. To resolve this problem, the replacement cost of the assets was replaced by the book value of the assets. Finally, Tobin's q is invaluable because, it is a good indicator that captures future growth opportunities and long-term financial performance as expected by the stock market (Aivazian, 2005).

\subsection{Share Price as a Measure of Firm Value}

The interest of shareholders in a company is measured in terms of the market value of their shareholdings, which is a reflection of their involvement in that company. In an efficient market, managers are expected to maximise the market value of the firm's shares if they are to act in the best interest of the shareholders. Several researchers have used share price or market value of equity as a proxy for firm value (Bao \& Bao, 1989, Horton, 2008) since changes in security prices could be inferred to mean that, market participants have predicted the future earnings of a company (Beaver, Lambert \& Morese, 1980).

Similarly, Lev and Thiagarajan (1993) opined that stock return is negatively related to annual changes in the ETR. This could be as a result of a negative signal to the persistent level of profits. In the study carried out by Liao, Lu and Chen (2009), it was observed that market will react positively to the announcement of stock bonuses which is an indication that the firm is doing well. Abowd and Kaplan (1999) in their study opined that stock price will increase if the award of a stock option is used as a means to motivate management because management will do all it could to maximise shareholders' value or the value of the company. According to Murphy (1998), stock options also indicate a direct relationship with the award given to the management and the appreciation of the share price, since the implementation of the option payments increased in line with rising stock prices. Thus, stock option compensation plan to managers could be considered as a good compensation plan because it will support the company's long-term performance, hence its value (Pasternack \& Rosemberg, 2002). This high performance will no doubt push the company's stock market price upward and will make investors respond positively by investing their funds in the company. 
As a representative of the firm value, the rising stock price shows that the firm value is also increasing. This position assumes that the investors are rational, so it is a fundamental aspect of the assessment. This is because, the value of the stock reflects the firm value, not only the intrinsic value of a moment but more importantly, is the expectation of the company' ability to increase the value of future prosperity.

\subsection{Tax Planning}

Tax is a contribution exacted by the state- Chambers English Dictionary (1992). Taxes are confined to compulsory, unrequested payments to government (OECD, 1988; vide Wilkinson, 1992:2). While planning is the "process of determining in advance the factors necessary to achieve a set of goals; designing an effective means of achieving some future goals (ends)- Kohler's Dictionary for Accountants (cooper \& Ijiri, 1984:383)". According to Lakhotia and Lakhotia (1998), tax planning takes minimum advantage of the exemptions, deductions, rebates, reliefs and other tax concessions allowed by tax statutes, leading to the reduction of the tax liability of the taxpayers.

According to Scholes and Wolfson (1992:3), "traditional approaches to tax planning fail to recognise that effective tax planning and tax minimisation are two different concepts. This is because, in a World of costly contracting, implementation of tax minimising strategies may introduce significant costs along non-tax dimensions. Therefore, the tax minimisation strategy may be undesirable". After all, a particularly easy way to avoid paying taxes is to prevent investing in profitable ventures. Thus, effective tax planning means not minimising taxes, but maximising after-tax rates of return on assets.

A Recent study by Slemrod (2004) proposed a new perspective on treating corporate tax planning with the agency theory developed by Jensen and Meckling in 1976. Tax planning is defined as all activities designed to produce a tax benefit (Wahab \& Holland, 2012). Slemrod (2004) opined that tax planning is of wider public interest since it can affect the level of provision of public goods which can then contribute to social issues. Non-governmental groups such as Oxfam (2009), Christian Aid (2009), and Trade Union Congress (2009) also examined tax planning from the social justice perspective. Desai et al. 2009) measured tax planning as the total book-tax differences (BTD) controlled for total accruals. Tax planning is seen as a veritable investment for shareholders because it reduces the tax burden that significantly weighs companies and shareholders (Chen, Chen, Cheng \& Shevlin, 2010). Although, shareholders may not promote the activities of tax planning because of the potential costs (Chen et al., 2010).

\subsection{Tax Planning and Firm Value}

Tax planning and firm value are anchored on two theoretical perspectives: the traditional theory and the theory of agency. The traditional theory of tax planning (or tax avoidance) is seen as leading because it increases after-tax earnings and it is in the interest of the shareholders. As a result of this, it is usually taken in valuation model. Tax planning activities that reduce or transfer resources from shareholders to the government should enhance shareholders wealth or firm value. The agency theory perspective of tax planning posits that tax planning can be complex and vague, and this can result to managerial opportunism. According to this theory, tax planning can lead to a reduction in firm value when managers may either have the opportunity to understate reported accounting profit or have the incentive to reduce corporate incentive tax liability by understating taxable income (Desai \& Dharmapala. 2009; Desai \& Dharmapala, 2006; Minnick \& Noga, 2010; Wahab \& Holland, 2012).

Desai and Dhamarpala (2009) investigated the relationship between tax avoidance activities and firm value using a sample of 862 U.S firms. In the research, tax avoidance is measured by a book-tax gap, while Tobin's q is the proxy for firm value. They found no significant direct relationship between tax avoidance activities and firm value. Wang (2010) examines the relationship between tax avoidance, corporate transparency, and firm value. The author used effective cash rates and permanent book-tax difference to measure tax avoidance with firm value as a proxy by Tobin's q and using S \& P 1500 firms in the period 1994-2001. The author found a positive significant relationship between tax avoidance and firm value.

Chashiandani and Martani (2012) examined the relationship between long-run tax avoidance behaviour and firm value by using a sample of non-banking and financial firms quoted on the Indonesian Stock Exchange between 2010 and 2011. The authors used a method similar to that employed by Dyreng Hanlon, \& Maydew (2008) who measured long-run tax avoidance and firm value is proxied by Tobin's' q. They found that long-run tax avoidance has a significant negative relationship with firm value, the study suggests that firm with lower ETR, has higher firm value. In the same vein, Desai and Dharmapala (2009) found no direct relationship between tax planning and market performance. The reasons for this indirect and insignificant relationship are the complex nature and tax implications of the transactions; hence, it becomes difficult for stakeholders to evaluate the performance of the firm fully. Tax planning can be measured by using Effective Tax Rate (ETR) and tax savings. 


\subsection{Effective Tax Rate (ETR) and Firm Value}

Effective tax rate is a measure of tax planning because; it decreases the tax liability of a firm without necessarily decreasing its accounting income (Derashid \& Zhang, 2003). It is calculated as the total tax expenses scaled by pre-tax accounting income. ETR assesses the tax performance of firms. It is a measure of a firm's tax burden. It provides a basic summary statistic of tax performance that describes the amount of tax paid by a company about its gross profit. ETR is seen to be appropriate as compared to book-tax gap measure. ETRs have been used by policymakers and interest groups in tax reform debates, especially those related to corporate tax provisions, the reason being that they summarise conveniently in one statistic, the cumulative effect of various tax preferences (Richardson \& Lanis, 2015). Shareholders usually value tax planning by using ETR information which reflects tax planning activities, and this is publicly available for shareholders scrutiny. Slemrod (2004), argued that shareholders could discipline management when the ETR is high because this high ETR could have a detrimental effect on share price.

Swenson (1999) found a negative relationship between ETR and share price because of the significant effects of a long-term sustainable reduction in ETR on market capitalization and shareholders' value. This finding is in tandem with the saying that a penny of tax savings could have a multiplying effect on the market value (Mintz, 1999). Because of this mixed result, it is suggested that shareholders should weigh tax planning related information in valuing firms, that is, only valid information about tax planning activities should be considered. Bauman and Shaw (2005) found that shareholders do not appear to impinge fully the earnings implication of interim ETR into share prices. In the author's opinion, it seemed that shareholders rely on audited information in the form of annual ETR as a measure of tax planning. This is consistent with some studies like Amir and Sougiannis, 1999; Desai and Hines, 2002; who found a positive relationship between tax planning and firm value. Abarbanell and Bushee (1997) found a negative correlation between ETR and share prices. The negative correlation is justified on the ground that, there are constraints on analysts' forecast in conveying earnings information in the short-run, and this leads to omission of value related information in the prediction. There is also, the failure on the part of the analyst to include the information that will influence investor's decision. There is also the problem of little attention on financial statement information which also influences the investor's general analysis or decision.

Previous studies such as Derashid and Zhang (2003), Adhikari, Derashid and Zhang (2006) and Rohaya, Nor'Azam and Bardai (2008) found a negative relationship between ETR and return on assets. The implication is that profit-making companies are likely to have lesser tax burdens due to the ability to take advantage of tax incentives and provisions to reduce their taxable income and hence lower ETR.

Intuitively, firm's profitability can influence effective tax rate especially when profitability is measured based on pre-tax income; we expect more profitable firms to have higher earnings and hence pay more taxes. This point of view is mostly evident in the literature. Gupta and Newberry (1997); Richardson and Lanis (2015); Minnick and Noga (2010); found a positive relationship between firms profitability and ETR. Rego (2003) and Derashid and Zhang (2003) opined that more profitable firms have a lower cost associated with managing taxes because they have more resources to invest in the planning activities that contribute to lower effective tax rates which therefore indicates a positive relationship between ETR and firm value. Even though, Bryant-Kutcher, Guejnther and Jackson (2011) found a negative correlation between ETR and firm value. According to them, differences in company income tax rate are not completely offset by non-tax expenses. Desai and Dharmapala (2006) are of the opinion that a negative relationship can exist between tax planning (ETR) and firm value due to information asymmetry between managers and shareholders. However, some studies found no direct association between firm value and tax planning (ETR) as a result of the effect of unquantifiable non-tax costs (Cloyd, Mills \& Weaver, 2003).

\subsection{Tax Savings and Firm Value}

Tax savings is the difference between statutory tax rate and effective tax rate. In a situation where a firm operates across some jurisdictions with different statutory tax rates, differences in these tax rates can provide a tax saving recognised in firm value. Tax savings used as a proxy for tax planning shows that managers have incentives to reduce financial statement tax expense because, tax planning is considered as a mechanism through which firms generate permanent tax savings and/or temporary tax savings achieved through deferrals (Ftouhi, Ayed \& Zemzem, 2010). Lisowsky, Lennox and Pittman (2013) found a positive relationship between firms that disclose a tax reserve in their financial statements and their use of tax shelters as a main mechanism to reduce the amount to taxes they pay. Atwood and Reynolds (2003), observed that tax savings affects firm value. Hence, they developed a test portfolio hedging. The author suggested that the shareholders should enhance tax losses as a component of tax planning depending on how the component is presented in the financial statements. Lisowsky et al. (2013) found a positive 
relationship between tax savings achieved through tax planning and business performance. This is because the cost of tax planning does not exceed the savings tax planning.

Against the above backdrop, it is evident that the issue of tax planning (ETR and tax savings) and firm value has not been foreclosed as a result of the measurement problems and inconsistencies in the empirical findings. These limitations create a substantial gap in the existing body of knowledge. Hence, our first proposition is that there is an insignificant relationship between tax planning and firm value.

\subsection{Firm Size and Firm Value}

By firm size, we mean how large a company is. There are different measures of firm size such as the number of employees, $\log$ of revenue, $\log$ of total assets and value added. The relationship between firm size and firm value is mixed. Lee (2009) and Josson (2007) recorded a positive correlation between firm size and firm value. To them, big firms are financially flexible. Hence, they can manipulate their cash flow to take advantage of investment opportunities. They equally have access to funds, lower financial difficulties and possibility of future growth. In the same vein, Hall and Weiss (1967), Majumdar (1997), Josson (2007), Serrasqueiro and Nunes (2008), Stierwald (2009), Saliha and Abdessatar (2011) found a positive relationship between firm size and profitability because profitability increases as the size of the firm expand. Big firms have more competitive power when compared to small firms and because they have a bigger market share, they have the opportunity to make more profit (Stierwald, 2009).

On the contrary, Banchuenvijit (2012), Becker-Blease, Kaen, Etebari and Baumann (2010) found a negative relationship between profitability and firm size because organization costs increase with firm size, at some points, these costs will outweigh the benefits from economies of scale and hence profitability will fall.

These inconsistencies in results and extant literature present a knowledge gap which forms a reasonable motivation for further study. Against the above backdrop, our second proposition is thus: there is no significant relationship between firm size and firm value.

\subsection{Dividend and Firm Value}

Dividend means the distribution of earnings among the shareholders of the business in proportion to their ownership. The primary goal of management is the maximisation of shareholders' wealth, and this translates into maximising the wealth of the business which is measured by the price of the company's common stock. Many arguments have been made about the dividend policy to be adopted by a company. Ordinary shareholders would see companies that pay dividends as honest and less susceptible to accounting manipulations. Gordon (1961) argues that embrace stocks that pay healthy dividends because this will indicate that the companies are making real profits instead of propagating creative accounting, this no doubt will affect the value of the firm positively.

A positive relationship exists between dividend and firm value because investors want dividends for self-control, they want to restrict themselves from consuming too much in the present, they do not want to dip into capital. Therefore, they only allow themselves to consume current income such as dividends (Shefrin \& Statman, 1984). The authors argued that retired investors (elderly) would rely on the incomes from their securities holding because they have little or no labour income. Hence, a positive relationship exists between dividend and firm value. Gordons (1961), in his "Bird in Hand Theory", supports the above argument based on future uncertainties towards dividends. A positive and significant relationship exists between dividend and firm value, because, a firm that has the policy to pay dividend will influence its profitability (John \& William, 1985; Miller \& Rock, 1985). In addition to firm value, dividend also affects share prices positively (Allen \& Michaely, 2002; Easterbrook, 1984; Gordon, 1961; Shefrin \& Statman, 1984).

Miller and Modigliani (1961), in their irrelevance theory of dividend, opines that a negative relationship exists between dividend and firm value because dividend policy is irrelevant for the cost of capital and firm's value when taxes or transaction costs are not taken into cognizance. They argued that as far as investors can raise income either by buying or selling shares, the expected return required to induce them to hold the firm's share will be at variance with payments and new issues of shares. Based on the above, they said dividend policy is irrelevant and as such, the firm can choose any payment pattern without affecting their value. These different theoretic and empirical literature present a methodological deficiency which makes the issue of dividend and firm value open for further consideration. Hence, we propose a non-significant relationship between dividend and firm value. 


\subsection{Leverage and Firm Value}

The leverage ratio is widely used to measure the portion of long term debts towards total assets of business organization's activities. It means the capability of a business organisation in financing its total assets with long-term debt (Danelova \& Sarka, 2011). Fama and French (2002) found a positive relationship between leverage and firm value. Ward and Price (2006) opined that an increased debt - equity ratio - increases shareholders' return because the firms are profitable ones, though this result may not be the same for non-profit making organization even if we do not have empirical justification for this proposition.

On the contrary, Rajan and Zingales (1995) found a negative relationship between leverage and profitability. The study result is consistent with De Wet (2006) who opined that a significant amount of value can be unlocked in moving closer to the optimal level of gearing. Modigliani and Miller (1963) conclude that the cost of equity of a firm increases the debt of the firm increases. Consistent with Rajan and Zingales (1995), Ruf (2008) opined that the leverage level of a business organization would result in a negative relationship with income tax expenses, and this negative correlation could be due to the interest in the long-term debts which might be used as a tax deductible item in business transaction activities and this will affect the value of the firm negatively. The combination of negative and positive results on the relationship between leverage and firm value shows that the issue is largely unsettled, and this creates a gap which requires further clarification. Hence, we propose an insignificant relationship between leverage and firm value.

\subsection{Research and Development and Firm Value}

Research and Development are measured by dividing research and development expenses by total sales from business activities of an organization. Research and Development investment leads firms to generate innovations that increase firm's profits (Aw, Roberts \& Xu, 2011). Firms will usually invest these profits in projects following such innovations to enhance their value. Increased tax credit will lead to an increase in R \& D expenditure, and this will, therefore, increase the firm's profitability and valuations (Moris, 2000). The effect of the increased tax credit will persist in the short run and reduce in the long-run because the growth in R \& D expenditure occasioned by increased tax credit will lead to a shift in the profitability distribution of firms in the economy.

A positive relationship exists between research and development and firm value because, first, firms that invest in $\mathrm{R}$ \& D will generate innovations that will increase their profitability (Bloom, Griffith \& VanReenen, 2002) and secondly, the profits derived from R \& D innovations are invested in physical capital to produce output, and this will also increase firm value (Doraszel, Ski \& Jaumandreu, 2013). Lach and Schankerman (1989) reported that the interaction of $\mathrm{R} \& \mathrm{D}$ expenditure and physical investment yields a positive relationship with firm value. However, the increase in the R \& D tax subsidy leads to an overall increase in R \& D expenditure, yet it will yield a smaller increase in the success rate of innovations (Hall \& Van Reenen, 2000). This could result in a negative relationship between $\mathrm{R} \& \mathrm{D}$ and firm value because, the benefits derived from the increased $\mathrm{R} \& \mathrm{D}$ tax subsidy over the long-run becomes smaller than the immediate short-run effect, the reason being that, the increased $\mathrm{R} \& \mathrm{D}$ expenditures changes the profitability, distribution, and therefore R \& D expenditures, of firms in the economy.

A negative relationship also exists between $\mathrm{R} \& \mathrm{D}$ and firm value because of uncertainties bedeviling the innovation process (Griliches, 1979). What this means is that, when a firm fails to invest when it ought to because of uncertainties in the economy, its returns will be negative and hence, it will affect the value of the firm. From the review, we observed that the relationship between $\mathrm{R} \& \mathrm{D}$ and firm value was vague. This vagueness reduces the extent of generalisation and thus creates a methodological shortcoming which future research can resolve. Hence, we propose an insignificant relationship between $\mathrm{R} \& \mathrm{D}$ and firm value.

\subsection{Capital Intensity and Firm Value}

Capital intensity is the cash invested in property, plants, and equipment of a business entity. The more capital invested, the more the firm is said to be capital intense, and this will affect the firm's value positively. According to Shahean and Malik (2012), capital intensity is the amount of investment made by business on their fixed assets, and it is measured by dividing non-current assets by total assets. A positive relationship exists between capital intensity and firm value (Shahean \& Malik, 2012). The reason being that, as the capital intensity of firm increases, it will increase its quality of production and on time production and hence the value of the enterprise will increase.

A negative relationship exists between capital intensity and firm value because, smaller firms are faced with greater capital constraints and this will affect their production level and hence the firm value (Leung, Meh \& Terajima, 2008). There exists a sparse empirical study on the relationship between capital intensity and firm value. The few 
existing studies are also inconsistent. This twin-problem are motivation for the future study. Therefore, our fifth proposition is thus: there is no significant relationship between capital intensity and firm value.

\section{Conclusion and Recommendations}

This paper seeks to examine the relationship between tax planning and firm value through a review of the extant literature. A literature review is relevant to identify milestones in academic research, knowledge gaps as well as to serve as reference point. There is a paucity of literature on corporate tax planning because the issue seems to be relatively young but fascinating and a fast burgeoning one. In the developed countries of Europe and America, some empirical attempts have been made, but the issue is still open for further discussion. The major challenge in our opinion is the inconsistency in research findings on the relationship between tax planning and firm value. Another issue is finding an appropriate measure of tax planning. Measuring tax planning is an indirect affair since it is either illegal or unethical and no company can own up to engaging in the process of tax reduction. In one strand of literature, tax planning has been measured by effective tax rate, in another strand of literature, tax planning was measured using tax savings. It is, therefore, important for researchers to find an appropriate measure for tax planning.

The review also revealed a general absence of theory in explaining the issue of tax planning even though some studies like Desai and Dharmpala (2006), Minnick and Noga (2010) and Wahab and Holland (2012) tried to explain the issue based on agency theory. This is a shortcoming for researches in tax planning because we need theories as background to empirical studies (Begg, Fisher \& Dornbusch, 2003). Another important revelation in our literature review is that the bulk of empirical studies on the dynamics of tax planning and firm value, are from developed economies even though this review is not enough to state emphatically that there is paucity of empirical literature in developing countries, none of the empirical studies reviewed focused on tax planning issues in Nigeria. Therefore, empirical studies on tax planning and firm value in Nigeria will facilitate fiscal policy and also enhance generalization on the subject of tax planning in developing countries with Nigeria as a reference point.

\section{References}

Abarbanell, J. S., \& Bushee, B. J. (1997). Fundamental analysis, future earnings, and stock prices. Journal of Accounting Research, 35(1), 1-24. http://dx.doi.org/10.2307/2491464

Abowd, J. M., \& Kaplan, D. S. (1999). Executive compensation: Six questions that need answering. J Econ Perspective, 13, 145-168. http://dx.doi.org/10.1257/jep.13.4.145

Adhikari, A., Derashid, C., \& Zhang, H. (2006). Public policy, political connections, and effective tax rates: Longitudinal evidence from Malaysia. Journal of Accounting and Public Policy, 25, 574-595. http://dx.doi.org/10.1016/j.jaccpubpol.2006.07.001

Aivazian, V. A. (2005). The impact of leverage on firm investment: Canadian evidence. Journal of Corporate Finance, 11(1-2), 277-291. http://dx.doi.org/10.1016/S0929-1199(03)00062-2

Allayannis, G., \& Weston, J. P. (2001). The use of foreign currency derivatives and firm market value. Review of Financial Studies, 14(1), 243-276. http://dx.doi.org/10.1093/rfs/14.1.243

Allen, F., \& Michaely, R. (2002). Policy payout. Centre for Financial Institutions Working Papers, 1-21.

Amir, E., \& Sougiannis, T. (1999). Analysts' interpretation and investors' valuation of tax carryforwards. Contemporary Accounting Research, 16 (1), 1- 34. http://dx.doi.org/10.1111/j.1911-3846.1999.tb00572.x

Atwood, T. J., \& Reynolds, J. K. (2008). The pricing of realized tax benefits from NOL carry forwards: Effect of income statement presentation. Journal of the American Taxation Association, 30(1), 1-27. http://dx.doi.org/10.2308/jata.2008.30.1.1

Aw, B. Y., Roberts, M. J., Xu, D. Y. (2011). R \& D investment exporting and productivity dynamics. American Economic Review, 101, 1312-1344. http://dx.doi.org/10.1257/aer.101.4.1312

Banchuenvilil, W. (2012). Determinants of firm performance of Vietnam listed companies. Academic and Business Research Institute.

Bao, B. H., \& Bao, D. H. (1989). Arm empirical investigation of the association $\mathrm{N}$ between productivity and firm value. Journal of Business Finance \& Accounting, 16(5), 699-717. http://dx.doi.org/10.1111/j.1468-5957.1989.tb00048.x

Bauman, M. P., \& Shaw, K. W. (2005). Disclosure of managers forecasts in interim financial statements: A study of effective tax rate changes. Journal of the American Taxation Association, 27(2), 57-82. http://dx.doi.org/10.2308/jata.2005.27.2.57 
Beaver. W.. Lambert. R., \& Morse, D. (1980). The information content of security prices. Journal of Accounting and Economics, 2(1), 3-28. http://dx.doi.org/10.1016/0165-4101(80)90013-0

Bebchuk, L. (2005). The growth of executive pay. Oxford Review Economic Pol, 21, 283-301. http://dx.doi.org/10.1093/oxrep/gri017

Becker-Blease, J. R., Keen, F. R., Etebari, A., \& Baumann, H. (2010). Employees firm size and profitability in U.S. manufacturing industries. Investment Management and Financial Innovations, 7(2), 7-23.

Begg, D., Fisher, S., \& Dornbusch, R. (2003). Economics ( $7^{\text {th }}$ ed.). London: McGraw-Hill.

Bhabra, G. S. (2007). Insider ownership and firm value in New Zealand. Journal of Multinational Financial Management, 17(2), 142-154. http://dx.doi.org/10.1016/j.mulfin.2006.08.001

Bhagat, S., \& Black, B. (2002). The non-correlation between board independence and long-term firm performance. Journal of Corporation Lan, 27 (January), 231-274.

Bloom, N. I., Griffith, R., \& Van-Reenen, J. (2002). Do R \& D tax audits work? Evidence from a panel of countries, 1979-1997. Journal of Public Economics, 85, 1-31. http://dx.doi.org/10.1016/S0047-2727(01)00086-X

Byrant-Kutcher, L. A., Guenther, D. A., \& Jackson, M. (2012). How do cross-country differences in corporate tax rates affect firm value? The Journal of the American Taxation Association, 34 (2), 1-17. http://dx.doi.org/10.2308/atax-10207

Chamber English Dictionary. New Delhi: Allide Publishers Ltd., 1992.

Chasbiandani, T., \& Martani, D. (2012). The effect tax avoidance long run to firm value (Pengaruh tax aviodance jangka pangang terhadap nilai perusahaan). Simposium National Accounting (Simposium Nasional Akuntansi). Banjarmasing Kalimantan Timur (east Kalimatan Provisi Indonesia): Ikatan Akuntan Indonesia (Associated Accountant Indonesia).

Chen. S., Chen, X., Cheng, Q., \& Shevlin, T. J. (2010). Are family firms more tax aggressive than non-family firms? Journal of Financial Economics, 95(1), 41- 61. http://dx.doi.org/10.1016/j.jfineco.2009.02.003

Christian Aid (2009). Christian aid pushes for tax justice in war on poverty. Press. Available from: wi'w. chrislianaid Releases. org. uk/presso/ilcepressreleasesfebruar)'2009/ChristianAid- tax-justice-campaign.apç [Accessed 22 December 2009].

Cloyd, C. B., Mills, L. F., \& Weaver, C. D. (2003). Firm valuation effects of the expatriation of US corporations to tax-haven countries. Journal of the American Taxation Association, 25(1), 87-109. http://dx.doi.org/10.2308/jata.2003.25.s-1.87

Cooper, W.W., \& Ijiri, Y. (1984). Kohler's dictionary for accountants. New Delhi: Prentice-Hall of India Private Ltd.

Danielova, A., \& Sarka, S. (2011). The effect of leverage on the tax-cut versus investment subsidy argument. Review of Financial Economics, 20(4), 123-129. http://dx.doi.org/10.1016/j.rfe.2011.10.001

De Wet, J. H. (2006). Determining the optimal capital structure: A practical contemporary approach. Meditan Accountancy Research, 14(2), 1-16. http://dx.doi.org/10.1108/10222529200600009

Derashid, C., \& Zhang, H. (2003). Effective tax rates and the "industrial policy" hypothesis: Evidence from Malaysia. Journal of International Accounting, Auditing and Taxation, 12(1), 45-62. http://dx.doi.org/10.1016/S1061-9518(03)00003-X

Desai, M. A., \& Dharmapala, D. (2006). Corporate tax avoidance and high powered incentives. Journal of Financial Economics, 79(1), 145-1 79. http://dx.doi.org/10.1016/j.jfineco.2005.02.002

Desai, M. A., \& Dharmapala, D. (2009). Corporate tax avoidance and firm value. The Review of Economics and Statistics, 91(3), 537-546. http://dx.doi.org/10.1162/rest.91.3.537

Desai, M. A., \& Hines, J. R. (2002). Expectations and expatriations: Tracing the causes and consequences of corporate inversions. National Tax Journal, $\quad$ 55(3), 409-440. http://dx.doi.org/10.17310/ntj.2002.3.03

Desai, M. A., \& Hines. J. R. Jr. (2002). Expectations and expatriations: Tracing the causes and consequences of corporate inversions. National Tax Journal, 55, 409-441. http://dx.doi.org/10.17310/ntj.2002.3.03 
Doraszelski, U., \& Jaumandreu, J. (2013). R \& D and productivity: Estimating endogenous productivity. Review of Economic Studies, 1, 21-42. http://dx.doi.org/10.1093/restud/rdt011

Dyreng, S. D., Hanlon, M., \& Maydew, E. L. (2008). Long-run corporate tax avoidance. The Accounting Review, 83, 61-82. http://dx.doi.org/10.2308/accr.2008.83.1.61

Easterbrook, F. (1984). Two agency-explanations of dividends. American Economic Review, 74, 650-659.

Fama, E., \& French, K. (2002). Testing trade-off and pecking order predictions about dividends and debt. The Review of Financial Studies, 15(1), 1-33. http://dx.doi.org/10.1093/rfs/15.1.1

Ftouhi, K., Ayed, A., \& Zemzem, A. (2010). Tax planning and firm value: Evidence from European companies. International Journal of Economics and Strategic Management of Business Process, 4, 1-9.

Gordon, M. (1961). The investment, financing and valuation of the corporation. Review of Economics and Statistics, $32-48$.

Griliches, Z. (1979). Issues in assessing the contributions of research and development to productivity growth. Bell Journal of Economics, 10, 92-116. http://dx.doi.org/10.2307/3003321

Gupta, S., \& Newberry, K. (1997). Determinants of the variability in corporate effective tax rates: Evidence from longitudinal data. Journal of Accounting and Public Policy, 16(1), 1-34. http://dx.doi.org/10.1016/S0278-4254(96)00055-5

Hall, B. H., \& Van-Reenen, J. (2000). How effective are fiscal incentives for R \& D? A review of evidence. Research Policy, 29, 449-469. http://dx.doi.org/10.1016/S0048-7333(99)00085-2

Hall, M., \& Weiss, L. (1967). Firm size and profitability. The Reviewing of Economics and Statistics, 49, 312-331. http://dx.doi.org/10.2307/1926642

Hanlon \& Heitzman, S. (2010). A review of tax research. Journal of Accounting and Economics, 50(2), 127-178. http://dx.doi.org/10.1016/j.jacceco.2010.09.002

Jensen, M. C., \& Meckling, W. H. (1976). Theory of the firm: Managerial behavior, agency costs and ownership structure. Journal of Financial Economics, 3(4), 305-360. http://dx.doi.org/10.1016/0304-405X(76)90026-X

John, K., \& Williams, J. (1985). Dividends, dilution and taxes: A signaling equilibrium. Journal of Finance, 40, 1053-1070. http://dx.doi.org/10.1111/j.1540-6261.1985.tb02363.x

Josson, B. (2007). Does the size matter? The relationship between size and profitability of Icelandic firms. Bifrost Journal of Social Sciences, 1, 43-55.

Lach, S., \& Schankerman, M. (1989). Dynamics of R \& D and investment in the scientific sector. Journal of Political Economy, 97, 880-904. http://dx.doi.org/10.1086/261632

Lakhotia, R. N., \& Lakhotia, S. (1998). Corporate tax planning. New Delhi: Vision Books.

Lee, J. (2009). Does size matter in firm performance? Evidence from U.S public firms. International Journal of the Economics of Business, 16(2), 189-203. http://dx.doi.org/10.1080/13571510902917400

Leung, D., Meh, C., \& Terajima, Y. (2008). Firm size and productivity. Bank of Canada, Working Paper, 2008-45.

Lev, B., \& Thiagarajan, S. R. (1993). Fundamental information analysis. Journal of Accounting Research, 31(2), 190-190. http://dx.doi.org/10.2307/2491270

Lewellen, W. G., \& Badrinath, S. G. (1997). On the measurement of Tobin's Q. Journal of Financial Economics, 44(1), 77-122. http://dx.doi.org/10.1016/S0304-405X(96)00013-X

Liao, M., Lu, \& Chen, Y. W. (2009). Market reaction to announcements of share-based payment. The International Journal of Economic Policy Studies, 4(7).

Lisowsky, P., Lennox C., \& Pittman, J. (2013). Tax aggressiveness and accounting fraud. Journal of Accounting Research, 51 (4), 739-778.

Majumdar, S. K. (1997). The impact of size and age and firm-level performance: Some evidence from India. Review of Industrial Organization, 12(2), 231-241. http://dx.doi.org/10.1023/A:1007766324749

McConnel1, J. J., \& Servaes, H. (1990) Additional evidence on equity ownership and corporate value. Journal of Financial Economics, 27(2), 595-612. http://dx.doi.org/10.1016/0304-405X(90)90069-C 
Miller, M. H., \& Modigliani, F. (1961). Dividend policy growth and the valuation of shares. Journal of Business, 34, 411-433. http://dx.doi.org/10.1086/294442

Miller, M. H., \& Rock, K. (1984). Dividend policy under asymmetric information. Journal of Finance, 40, 1031-1051. http://dx.doi.org/10.1111/j.1540-6261.1985.tb02362.x

Minnick, \& Noga, T. (2010). Do corporate governance characteristic influence tax management. Journal of Corporate Finance, 16, 703-718. http://dx.doi.org/10.1016/j.jcorpfin.2010.08.005

Mintz, S. L. (1999). A taxing challenge forget death. CFO Magazine. Available from: http://www.cfö.com article. fin 298'63O [Accessed 9 September 2008].

Modigliani, F., \& Miller, M. (1963). Corporate income taxes and the cost of capital: A correction. The American Economic Review, 53(3), 433-444.

Morck, R., Shellfire, A., \& Vishny, R. (1988). Management ownership and market valuation: An empirical analysis. Journal of Financial Economics, 20(1/2), 293-315. http://dx.doi.org/10.1016/0304-405X(88)90048-7

Moris, F. (2005). The U.S research and experimentation tax credit in the 1900s. National Science Foundation, Info Brief NSFOS-316, Arlington, VA.

Murphy, K. (1998). Corporate performance and managerial remuneration: An empirical analysis. J Acc Econ, 7 , 11-42. http://dx.doi.org/10.1016/0165-4101(85)90026-6

OECD (1988). Harmful tax competition: An emerging global issue. More Information on the Harmful Tax Practices Work. Available from: http://wwoecd.org/dataeoecd/33/3/190184 .pdf [Accessed 22 December 2009].

Oxfam (2009). Tax haven crackdown could deliver $\$ 1$ 2Obn a year to fight poverty-Oxfam. News. Available from: witw. oxfizm. org.uk/applications/blogs pressof7lce ? $p=3912$ [Accessed 22, December 2009].

Pasternack, D., \& Rosenberg, M. (2002). The impact of stock option incentive on investment and firm value. Department of Finance and Statistics, Swedish School of Economics and Business Administration, 00101 Helsinki, E-mail: publ@shh.fi, and internet: http://www.sh.fi/services/biblio/papers/index.htm.

Permatasari, G. R., \& Martani, D. (2012). Effect of earning management and tax planning to earning information content of manufacturing companies in Indonesia. International Conference on Business and Economics Research (rd ICBER), (pp. 2272-2287). Bandung.

Rajan, R. G., \& Zingales, L. (1995). What do you know about capital structure? Some evidence from international data. The Journal of Finance, 50(5), 1421-1460. http://dx.doi.org/10.1111/j.1540-6261.1995.tb05184.x

Rego, S. O. (2003). Tax-avoidance activities of U.S. multinational corporations. Contemporary Accounting Research, 20(4), 805-833. http://dx.doi.org/10.1506/VANN-B7UB-GMFA-9E6W

Richardson, G., \& Lanis, R. (2015). Determinants of the variability in corporate effective tax rates and tax reform: Evidence from Australia. Journal of Accounting and Public Policy, 26(6), 689-704. http://dx.doi.org/10.1016/j.jaccpubpol.2007.10.003

Rohaya, M. N., Nor'Azam, M., \& Bardai, B. (2008). Corporate effective tax rates: A study on Malaysian public listed companies. Malaysian Accounting Review, 7(1), 1-20.

Ruf, M. (2008). How can firms choose their leverage? - Tax planning for implementing tax induced debt finance how can firms choose their leverage, 30-31. http://dx.doi.org/10.2139/ssrn.120663

Saliha, T., \& Abdessatar, A. (2011). The determinants of financial performance: An empirical test using the simultaneous equation method. Economics and Statistics Review, 10(1), 1-19.

Scholes, M. S., \& Wolfson, M. A. (1992). Taxes and Business Strategy: A Planning Approach. New Jersey: Prentice Hall.

Serrasqueiro, Z. S., \& Nunes, P. M. (2008). Performance and size: Empirical evidence from Portuguese SMEs. Small Business Economics, 31(2), 195-217. http://dx.doi.org/10.1007/s11187-007-9092-8

Shaheen, S., \& Malik, Q. A. (2012). The impact of capital intensity, size of firm and profitability on debt financing in textile industry of Pakistan. Interdisciplinary Journal of Contemporary Research in Business, 3(10), 1061-1066. 
Shefrin, H. M., \& Statman, M. (1984). Explaining investor preference for cash dividend(s). Emerging Markets Quarterly, 5, 39-49. http://dx.doi.org/10.1016/0304-405x(84)90025-4

Slemrod, J. (2004). The economics of corporate tax selfishness. National Tax Journal, 57(4), 877-899. http://dx.doi.org/10.17310/ntj.2004.4.06

Stierwald, A. (2009). Determinants of firm profitability - The effect of productivity and its persistence. Melbourne Institute of Applied Economic and Social Resource, 9, 152.

Swenson, C. (1999). Increasing stock market value by reducing effective tax rates. Tax Notes, June 7, 1503-1505.

The Guardian (2009). Firms' secret tax avoidance schemes cost UK billions: Investigation into the complex and confidential world of tax. Tax Gap Reporting. Available from: avoidance [Accessed 2 February 2009].

Tobin, J. (1969). A general equilibrium approach to monetary theory. Journal of Money, Credit and Banking, 1(1), 15-29. http://dx.doi.org/10.2307/1991374

Trade Union Congress (2009). The missing billions the UK tax gap. Touchstone Pamphlets. Available from: www. luc. omy. UK iouchsiomme.Uissin, billions]missin.bilIzons.pd/ [Accessed 22 December 2009].

Wahab, N. S., \& Holland, K. (2012). Tax planning, corporate governance and equity value. The British Accounting Review, 44, 111-124. http://dx.doi.org/10.1016/j.bar.2012.03.005

Wang, T. X. (2010). Tax avoidance, corporate transparency, and firms value. Retrieved 2013, from http://ssrn.com.

Ward, M., \& Price, A. (2006). Turning vision into value. Pretoria: Van Schaik Publishers.

Wilkinson, M. (1992). Taxation. Hong Kong: The Macmillan Press. http://dx.doi.org/10.1007/978-1-349-21989-6 